\title{
Early selection and classification of yerba mate progenies
}

\author{
Ivar Wendling ${ }^{(1)}$, José Alfredo Sturion ${ }^{(1)}$, Carlos André Stuepp ${ }^{(2)}$, Cristiane Aparecida Fioravante Reis(1), \\ Magno Antonio Patto Ramalho(3) and Marcos Deon Vilela de Resende ${ }^{(1)}$
}

\begin{abstract}
(1)Embrapa Florestas, Estrada da Ribeira, Km 111, Caixa Postal 319, CEP 83411-000 Colombo, PR, Brazil. E-mail: ivar.wendling@embrapa.br, jose.sturion@embrapa.br, cristiane.reis@embrapa.br, marcos.resende@embrapa.br (2)Universidade Estadual de Ponta Grossa, Departamento de Fitotecnia e Fitossanidade, Campus de Uvaranas, Bloco F, Sala 08, Avenida Carlos Cavalcanti, no 4.748, CEP 84030-900 Ponta Grossa, PR, Brazil. E-mail: castuepp@uepg.br (3)Universidade Federal de Lavras, Departamento de Biologia, Caixa Postal 3.037, Campus Universitário, CEP 37200-000 Lavras, MG, Brazil. E-mail: magnoapr@dbi.ufla.br
\end{abstract}

\begin{abstract}
The objective of this work was to evaluate the feasibility of early selection of open-pollinated yerba mate (Ilex paraguariensis) progenies, and to classify the best parents and candidates for clones. The germplasm is composed of 140 progenies collected from areas within the natural distribution of the species in Southern Brazil and a commercial genotype (control). The experiment was established in Ivaí, in the state of Paraná, Brazil, in March 1997, in randomized complete blocks, with ten replicates, and linear plots of six plants. The commercial mass (kg per plant) of leaves and branches smaller than $7 \mathrm{~mm}$ was harvested at 2.5 , $4.5,6.5$, and 18.7 years of age. The statistical evaluation was performed using the mixed model procedure with restricted maximum likelihood/best linear unbiased prediction, using the Selegen software. High selective accuracy, significant progeny effects, and genetic variability for commercial mass production were observed for the four harvesting ages. The application of early selection for leaf mass production is feasible for yerba mate progenies harvested at 6.5 years. The selection of the best trees, either for use as parents or as candidates for cloning, provides significant gains for the genetic breeding of yerba mate.
\end{abstract}

Index terms: Ilex paraguariensis, cloning, genetic correlation, progeny $\mathrm{x}$ harvesting-age interaction.

\section{Seleção precoce e classificação de progênies de erva-mate}

Resumo - O objetivo deste trabalho foi avaliar a viabilidade da seleção precoce de progênies de polinização aberta de erva-mate (Ilex paraguariensis) e classificar os melhores genitores e candidatos a clones. O germoplasma é composto por 140 progênies coletadas em áreas de distribuição natural da espécie na região Sul do Brasil e um genótipo comercial (testemunha). O experimento foi implantado em Ivaí, PR, em março de 1997, em blocos ao acaso, com dez repetições, e parcelas lineares de seis plantas. A massa comercial (kg por planta) com folhas e galhos menores que $7 \mathrm{~mm}$ foi colhida aos 2,5, 4,5, 6,5 e 18,7 anos de idade. A avaliação estatística foi realizada por meio do procedimento de modelos mistos com máxima verossimilhança restrita/melhor predição linear não viesada, por meio do programa Selegen. Elevada acurácia seletiva, efeitos significativos de progênies e variabilidade genética para a produção de massa comercial foram observados nas quatro idades de colheitas. A aplicação da seleção precoce para a produção de massa foliar é viável para as progênies na colheita aos 6,5 anos. A seleção das melhores árvores, seja para uso como genitoras em cruzamentos ou como candidatas à clonagem, proporciona ganhos significativos para o melhoramento de erva-mate.

Termos para indexação: Ilex paraguariensis, clonagem, correlação genética, interação progênie x idade de colheita.

\section{Introduction}

In Brazil, the leaf mass of Ilex paraguariensis A. St. Hil., commonly known as yerba mate or Paraguay tea, is obtained from crops $(602,899$ tonnes per year) and native extractivism (515,451 tonnes per year), primarily in the states of Paraná, Rio Grande do Sul, and Santa Catarina (IBGE, 2015). The crop is economically relevant, with an estimated production value of
R\$ 975.5 million (IBGE, 2015), and a production chain that is composed of a significant number of small producers and industries. However, low-leaf mass productivity is common, which is due mainly to the need for improved silviculture techniques, as well as to the low genetic and physiological quality of the seed used in the crops (Simeão et al., 2002; Sturion \& Resende, 2010). 
Therefore, in order to obtain bred clones and seeds, in the 1990s, breeding programs were started in Brazil, which are currently conducted by Embrapa Florestas and Empresa de Pesquisa Agropecuária e Extensão Rural de Santa Catarina (Epagri). Open-pollinated provenances and progenies of yerba mate have been evaluated in several environmental conditions, which constitute the base-breeding populations (Sturion \& Resende, 2010).

These programs aim at selecting genotypes with additional adaptive traits to environmental cultivation conditions, high-leaf mass production, and tolerance to biotic and abiotic factors. Recently, emphasis has been placed on the inclusion traits linked to the content of some relevant chemical compounds that can directly affect the quality of commercial products and on their biological effects (Morais et al., 2009; González de Mejía et al., 2010; Sturion \& Resende, 2010; Anesini et al., 2012; Barbosa et al., 2015; Blum-Silva et al., 2015; González Arbeláez et al., 2016; Cardozo Junior $\&$ Morand, 2016). However, increasing productivity is always desirable for breeding programs.

Selecting yerba mate trees, based on the leaf mass production, is extremely laborious (Sturion \& Resende, 2010; Santin et al., 2015; Wendling et al., 2016). This activity includes pruning, removal of parts of leaves and branches, and quantification of the leaf mass of each tree. In addition, because this plant is a long-lived perennial species, it is problematic to wait until later ages to make such selection (Santin et al., 2014). In this case, proving the efficacy of early selection for leaf mass production in yerba mate would bring greater gains per unit of time, since it would reduce the time spent on the generation of cultivars.

The feasibility of early selection was verified for traits related to the production of wood in Eucalyptus species (Marques Júnior et al., 1996; Pereira et al., 1997; Massaro et al., 2010; Lima et al., 2011; Beltrame et al., 2012). However, information on the feasibility of early selection in yerba mate is scarce (Scherer, 2001; Sturion \& Resende, 2010).

The objective of this work was to evaluate the feasibility of early selection of open-pollinated yerba mate progenies, and to classify the best parents and candidates for clones.

\section{Materials and Methods}

For the progenies trial, seed from parent trees were collected in seven areas where yerba mate is naturally distributed, located in the following Brazilian municipalities: Antônio Olinto, 21 progenies; Barão do Cotegipe, 21 progenies; Cascavel, 25 progenies; Colombo, 25 progenies; Ivaí, 25 progenies; Pinhão, 25 progenies; and Quedas do Iguaçu, 25 progenies. Except for Barão do Cotegipe, in the state of Rio Grande do Sul, all the other municipalities locate in the state of Paraná. At each seed collection site, the number of sampled trees ranged from 1 to 25 , resulting in 164 open-pollinated progenies of yerba mate, out of which 140 were evaluated in the present experiment, besides a commercial control.

Seedlings were produced according to the recommended silvicultural protocol for the species. In March 1997, the progeny trial was established in the municipality of Ivaí, in the state of Paraná, Brazil

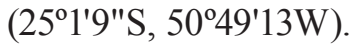

The experiment was installed in a randomized complete block design, with ten replicates, and linear plots with six plants. The 141 treatments were randomized regardless of their origins and had no hierarchical arrangement of progenies within the provenances. The spacing used for planting was $3 \times 2 \mathrm{~m}$.

The experimental area was predominantly formed by a Latossolo Vermelho distrófico (Rhodic Hapludox). The soil is deep, well drained, porous, with high-clay saturation (72\%), and dark-reddish color. Chemically, it is acidic, with low-base saturation and high-aluminum saturation. Originated from sedimentary rocks (argillite), the relief is smoothly undulated, with slopes around $4 \%$. The average altitude is $750 \mathrm{~m}$.

The climate type, according to Köppen-Geiger's classification, is Cfa, which corresponds to humid subtropical climate with hot summers, infrequent frosts, and the tendency of rains to concentrate in the summer months, without a defined dry season. Estimated minimum and maximum annual temperatures are 12.7 and $24.9^{\circ} \mathrm{C}$, respectively, and the average annual temperature is $17.8^{\circ} \mathrm{C}$. Mean annual rainfall is $1,588.60 \mathrm{~mm}$; and the mean annual relative humidity is $79.7 \%$.

The commercial production of mass ( $\mathrm{kg}$ per plant) of leaves and branches smaller than $7 \mathrm{~mm}$ was harvested at $2.5,4.5,6.5$, and 18.7 years of plant age. The mixed model procedure was performed in the statistical analysis, using the restricted maximum likelihood/best linear unbiased prediction (REML/Blup) (Resende, 2007a) in the software Selegen (Resende, 2007a). In the 
analyses, the effects of provenances were disregarded, according to the early selection evaluation methods proposed by Marques Júnior et al. (1996) and Pereira et al. (1997).

To evaluate each plant age at harvest, the model $\mathrm{y}=\mathrm{Xr}+\mathrm{Za}+\mathrm{Wp}+\mathrm{e}$ was used, in which: $\mathrm{y}$ is the data vector; $r$ is the vector of the fixed effects of replicate added to the general average; $a$ is the vector of the individual additive genetic random effects; $p$ is the vector of random effects of plots; and e is the vector of residue random effects. For the joint analyses, the model $\mathrm{y}=\mathrm{Xm}+\mathrm{Za}+\mathrm{Wp}+\mathrm{Qi}+\mathrm{Ts}+\mathrm{e}$ was used, in which $y$ is the data vector; $m$ is the vector of the fixed effects of the measurement-repeat combinations, added to the general mean; $a$ is the vector of the individual additive genetic random effects; $p$ is the vector of random effects of plots; $i$ is the vector of random effects of progenies $\mathrm{x}$ harvesting-ages interaction; $\mathrm{s}$ is the vector of the permanent random effects of individuals; and e is the vector of residue random effects. Capital letters represent the incidence matrices for these effects (Resende, 2007a).

From these analyses, the deviances and significance of the random effects of the models were obtained using the likelihood ratio test (LRT) (Resende, 2007b). The estimates of accuracy and genetic and phenotypic parameters of the progenies were calculated for each age at harvest and in the joint analyses of ages. Further details are described by Resende (2007b).

To determine the efficiency of early selection, the following methodologies were used: fluctuation of genetic and phenotypic parameters over the ages (Marques Júnior et al., 1996; Pereira et al., 1997; Lima et al., 2011); magnitude of the progenies x harvestingages interactions (Marques Júnior et al., 1996; Pereira et al., 1997; Lima et al., 2011); estimate of the genetic correlation at different ages at harvest (Lambeth, 1980; Lima et al., 2011); and response correlated with selection (Marques Júnior et al., 1996; Pereira et al., 1997; Lima et al., 2011).

\section{Results and Discussion}

According to the classification proposed by Resende (2007b), the selective accuracy estimates for leaf mass production were of high magnitude for each evaluated age of harvest (Table 1). For genetic breeding experiments, accuracy values above $70 \%$ are desirable (Resende \& Duarte, 2007; Resende, 2007b). Accuracy is essential in the selection processes, since it consists of the correlation between the true genotypic or genetic additive value and that predicted from field data (Resende, 2007b).

The average number of trees in production during harvests was approximately $85.20 \%$ out of a total of 8,460 trees. The mean values of leaf mass production per tree at each age were in line with other experiments at similar ages (Sturion \& Resende, 2010). Thus, the results reflect a good adaptation of the introduced material to the environmental conditions of Ivaí.

In the deviance analyses, significant progeny effects were observed through the LRT test, at $1 \%$ probability, for each age at harvest (Table 1). These results reveal the possibility of gain with the selection for leaf mass production.

The estimates of the additive genetic variance were high in relation to those of the environmental variance between plots and residual (environmental + nonadditive) (Table 2). Therefore, in general, most of the phenotypic variance was explained by the additive variance, associated with the population with

Table 1. Analysis of deviances for leaf mass production $(\mathrm{kg})$ for each harvest age $(2.5,4.5,6.5$, and 18.7 years), from open-pollinated progenies of yerba mate (Ilex paraguariensis), in the municipality of Ivaí, in the state of Paraná, Brazil.

\begin{tabular}{|c|c|c|c|c|c|c|c|c|}
\hline \multirow[t]{2}{*}{ Source of variation } & \multicolumn{2}{|c|}{2.5 years } & \multicolumn{2}{|c|}{4.5 years } & \multicolumn{2}{|c|}{6.5 years } & \multicolumn{2}{|c|}{18.7 years } \\
\hline & Deviance & LRT $^{(1)}$ & Deviance & LRT & Deviance & LRT & Deviance & LRT \\
\hline Progenies $^{(2)}$ & $-2,487.08$ & $402.43 * *$ & $11,725.60$ & $595.45 * *$ & $22,464.53$ & $527.12 * *$ & $28,011.51$ & $310.47^{* *}$ \\
\hline Plots $^{(2)}$ & $-2,669.94$ & $219.57 * *$ & $11,206.47$ & $76.32 * *$ & $22,089.86$ & $152.45 * *$ & $27,915.85$ & $214.81 * *$ \\
\hline Complete model & $-2,889.51$ & - & $11,130.15$ & - & $21,937.41$ & - & $27,701.04$ & - \\
\hline Accuracy $(\%)$ & \multicolumn{2}{|c|}{93.05} & \multicolumn{2}{|c|}{95.70} & \multicolumn{2}{|c|}{95.70} & \multicolumn{2}{|c|}{92.60} \\
\hline Number of trees in production $(\%)$ & \multicolumn{2}{|c|}{$8,172(96.60)$} & \multicolumn{2}{|c|}{$7,515(88.80)$} & \multicolumn{2}{|c|}{$6,802(80.40)$} & \multicolumn{2}{|c|}{$6,355(75.10)$} \\
\hline Average & \multicolumn{2}{|c|}{0.6826} & \multicolumn{2}{|c|}{1.4707} & \multicolumn{2}{|c|}{4.1308} & \multicolumn{2}{|c|}{6.9339} \\
\hline
\end{tabular}


high genetic variability and adequate sample size, as observed by Sturion \& Resende (2010). The evaluated progenies consisted of wild material from areas of natural occurrence of yerba mate in the states of Paraná and Rio Grande do Sul, which contributed to the high coefficients of additive genetic and genotypic variation among progenies. High values of coefficients of additive genetic variation for leaf mass production in yerba mate were also reported by Simeão et al. (2002) and Sturion \& Resende (2010).

Table 2. Estimates of variance components for leaf mass production $(\mathrm{kg})$ for each age at harvest, from openpollinated progenies of yerba mate (Ilex paraguariensis), in the municipality of Ivaí, in the state of Paraná, Brazil.

\begin{tabular}{|c|c|c|c|c|}
\hline \multirow[t]{2}{*}{ Estimate $^{(1)}$} & \multicolumn{4}{|c|}{ Age at harvest (years) } \\
\hline & 2.5 & 4.5 & 6.5 & 18.7 \\
\hline $\mathrm{Va}$ & 0.1778 & 1.5429 & 10.1611 & 22.1785 \\
\hline Vplot & 0.0316 & 0.1130 & 1.0154 & 4.2118 \\
\hline Vresidual & 0.0900 & 0.2833 & 0.3519 & 7.7273 \\
\hline Vpi & 0.2994 & 1.9393 & 11.5285 & 34.1177 \\
\hline$h^{2} \mathrm{a}$ & 0.5939 & 0.7956 & 0.8814 & 0.6500 \\
\hline CI $\left(h^{2} a\right)$ & $\begin{array}{c}(0.5457- \\
0.6421)\end{array}$ & $\begin{array}{c}(0.7374- \\
0.8538)\end{array}$ & $\begin{array}{c}(0.8170- \\
0.9458)\end{array}$ & $\begin{array}{c}(0.5928- \\
0.7072)\end{array}$ \\
\hline $\mathrm{h}^{2} \mathrm{pm}$ & 0.8659 & 0.9161 & 0.9155 & 0.8578 \\
\hline$c^{2}$ plot & 0.1055 & 0.0583 & 0.0880 & 0.1234 \\
\hline $\mathrm{CV}_{\mathrm{gi}}(\%)$ & 61.7702 & 84.4594 & 77.1669 & 67.9275 \\
\hline $\mathrm{CV}_{\mathrm{gp}}(\%)$ & 30.8851 & 42.2297 & 38.5834 & 33.9637 \\
\hline $\mathrm{CV}_{\mathrm{e}}(\%)$ & 38.4285 & 40.4049 & 37.0647 & 41.4845 \\
\hline $\mathrm{CV}_{\mathrm{r}}$ & 0.8037 & 1.0452 & 1.0409 & 0.8187 \\
\hline
\end{tabular}

${ }^{(1)} \mathrm{Va}$, additive genetic variance; Vplot, environmental variance between plots; Vresidual, residual variance (environmental + nonadditive); Vpi, individual phenotypic variance; $h^{2} a$, narrow-sense heritability; CI $\left(h^{2} a\right)$, confidence interval of the narrow-sense heritability; $h^{2} \mathrm{pm}$, heritability at the level of progeny means; $\mathrm{c}^{2}$ plot, coefficient of determination of plot effects; $\mathrm{CV}_{\mathrm{gi}}(\%)$, coefficient of individual additive genetic variation; $\mathrm{CV}_{\mathrm{gp}}(\%)$, coefficient of individual additive genetic variation between progenies; $\mathrm{CV}_{\mathrm{e}}(\%)$, coefficient of environmental variation; and $\mathrm{CV}_{\mathrm{r}}$, coefficient of relative variation.
Estimates of the additive genetic variance and the phenotypic variance increased throughout the harvests. However, estimates of variation coefficients of additive genetic and genotypic variance among progenies reached their highest values at 4.5 years. Additionally, the estimates of the coefficient of relative variation were identical for 4.5 and 6.5 years of age. These results suggest the feasibility of early selection.

The values of the residual variance, as already mentioned, were of lower magnitude than the additive genetic variance. As these values represent openpollinated progenies and analysis for each age at harvest, previous observations show that the residual variance can also be inflated by the dominance and the epistatic variances, and by variances in the progenies $\mathrm{x}$ harvesting-ages interactions (Vencovsky \& Barriga, 1992).

The narrow-sense heritability values were higher than 0.59 for different ages of harvest, and different from zero, according to the confidence intervals. The narrow-sense heritability considers only the additive genetic variance, that is, that which is fixed by selection and important in sexual propagation (Vencovsky \& Barriga, 1992; Sturion \& Resende, 2010). As expected, the heritability at the level of progenies means were even higher and above 0.85 . These results reflect a high-experimental accuracy and high-genetic variability. Similar heritability values for leaf mass were reported by Sturion \& Resende (2010), and were higher than those found by Costa et al. (2005), for the traits of height and diameter at breast height.

In order to verify the feasibility of early selection, joint analyses for age at harvest were performed, two-by-two (Table 3). Significant effects of progenies and permanent environments were detected in the deviance analyses,

Table 3. Analysis of combined deviance of two-by-two harvest ages (2.5/18.7, 4.5/18.7, and 6.5/18.7 years) for leaf mass production in open-pollinated progenies of yerba mate (Ilex paraguariensis), in the municipality of Ivaí, in the state of Paraná, Brazil.

\begin{tabular}{|c|c|c|c|c|c|c|}
\hline \multirow[t]{2}{*}{ Source of variation } & \multicolumn{2}{|c|}{$2.5 / 18.7$ years } & \multicolumn{2}{|c|}{$4.5 / 18.7$ years } & \multicolumn{2}{|c|}{$6.5 / 18.7$ years } \\
\hline & Deviance & $\mathrm{LRT}^{(1)}$ & Deviance & LRT & Deviance & LRT \\
\hline Progenies $^{(2)}$ & $60,641.54$ & 1.01 & $61,230.85$ & $21.04 * *$ & $63,497.59$ & $188.19^{* *}$ \\
\hline Plots $^{(2)}$ & $60,933.56$ & $293.03 * *$ & $61,483.61$ & $273.89 * *$ & $63,542.34$ & $232.94 * *$ \\
\hline Progenies $\mathrm{x}$ ages at harvest ${ }^{(2)}$ & $61,866.22$ & $1,225.69 * *$ & $62,016.27$ & $806.46^{* *}$ & $63,490.17$ & $180.77 * *$ \\
\hline Permanent environments & $60,642.07$ & 1.54 & $61,270.32$ & $60.51 * *$ & $64,682.71$ & $1,373.31 * *$ \\
\hline Complete model & $60,640.53$ & - & $61,209.81$ & - & $63,309.40$ & - \\
\hline
\end{tabular}

(1) Probability likelihood ratio test (LRT), with 1 degree of freedom. ${ }^{(2)}$ Deviance of the model adjusted without these effects. $* *$ Significant by the chi-squared test, at $1 \%$ probability. 
using the LRT test at $1 \%$ probability, except for analyses for plants between 2.5 and 18.7 years.

The effects of the progenies $\mathrm{x}$ harvesting-ages interaction were significant for all the joint analyses. The presence of complex-type interaction (with low-genetic correlation between harvests) reflects the noncoincident behavior of progenies between pairs of age at harvest (Vencovsky \& Barriga, 1992). It was also noted that the variance percentage of progenies $\mathrm{x}$ harvesting-ages interactions, in relation to the additive genetic variance was considerable for the age pairs 2.5 and 18.7 years, and 4.5 and 18.7 years (Table 4 ). These aspects, coupled with the high residual variance and the low values of genetic correlation, repeatability and heritability, at the level of progeny means, make it unfeasible the early selection at 2.5 and 4.5 years of age.

The variance percentage of progenies $\mathrm{x}$ harvestingages interactions in relation to the additive variance for the age pair 6.5 and 18.7 years was of low magnitude (Table 4). In addition, this age pair obtained the

Table 4. Estimates of variance components of the combined analyses of ages at harvest, two-by-two, for leaf mass production $(\mathrm{kg})$ from a test of open-pollinated progenies of yerba mate (Ilex paraguariensis), in the municipality of Ivaí, in the state of Paraná, Brazil.

\begin{tabular}{lccc}
\hline Estimate $^{(1)}$ & \multicolumn{3}{c}{ Pairs of age at harvest (years) } \\
\cline { 2 - 4 } & $2.5 / 18.7$ & $4.5 / 18.7$ & $6.5 / 18.7$ \\
\hline $\mathrm{Vg}$ & 0.2460 & 1.1345 & 3.6989 \\
Vplot & 0.9375 & 1.0621 & 1.5461 \\
Vint & 2.3854 & 1.6325 & 0.4088 \\
Vperm & 0.1808 & 1.1108 & 6.2427 \\
Vresidual & 11.8539 & 11.3860 & 9.2969 \\
Vpi & 15.6036 & 16.3259 & 21.1935 \\
Vint/Vg $\%$ ) & 969.67 & 143.89 & 11.05 \\
$\mathrm{~h}^{2} \mathrm{~g}$ & 0.0158 & 0.0695 & 0.1745 \\
$\mathrm{CI}\left(\mathrm{h}^{2} \mathrm{~g}\right)$ & $0.0130-0.0185$ & $0.0638-0.0752$ & $0.1654-0.1836$ \\
$\mathrm{r}$ & 0.0874 & 0.2026 & 0.5420 \\
$\mathrm{CI}(\mathrm{r})$ & $0.0810-0.0938$ & $0.1928-0.2124$ & $0.5460-0.5580$ \\
$\mathrm{c}^{2}$ plot & 0.0601 & 0.0651 & 0.0729 \\
$\mathrm{c}^{2}$ int & 0.1529 & 0.0999 & 0.0193 \\
$\mathrm{c}^{2}$ perm & 0.0116 & 0.0680 & 0.2946 \\
rgharvest & 0.0935 & 0.4100 & 0.9005 \\
\hline (Ig. & & &
\end{tabular}

${ }^{(1)} \mathrm{Vg}$, genotypic variance among progenies, equal to $1 / 4$ of the additive genetic variation; Vplot, environmental variance between plots; Vint, variance of progenies $x$ harvestingage interactions; Vperm, variance of the permanent effects; Vresidual, temporary residual variance; Vpi, individual phenotypic variance; $\mathrm{h}^{2} \mathrm{~g}$, heritability at the level of progeny means; CI $\left(\mathrm{h}^{2} \mathrm{~g}\right)$, confidence interval of the heritability at the level of progeny means; $r$, individual repeatability; $\mathrm{c}^{2}$ plot, coefficient of determination of plot effects; $c^{2}$ int, coefficient of determination of the progenies $x$ harvestingage interactions; c2perm, coefficient of determination of the permanent effects; rgharvest, genetic correlation through harvests. highest values of heritability, repeatability, and genetic correlation between harvests. Therefore, at the beginning, 6.5 years would be the best time to make the early selection for leaf mass production of yerba mate.

In addition, the estimation was considerable for the annual expected gain, with the selection at 18.7 years and the response correlated with the selection at 6.5 years, besides being superior to that obtained for the other age pairs (Table 5). Although the gain observed at 18.7 years was of great magnitude, that obtained one at 6.5 years, associated with the high-genetic correlation between progeny performances in these two ages at harvest, makes it possible to use the selection at 6.5 years. Therefore, rather than waiting another 12 years to complete the selection cycle, the early selection allows of two more generations to be selected, with numerous advantages for forest producers to appropriate the selection gain more quickly. As for the breeding program, it is worth noting that during this period it is possible to carry out early selection, start the clonal evaluation, and recombine the best clones.

The efficiency of early selection was also verified for traits related to the production of wood for Eucalyptus (Marques Júnior et al., 1996; Pereira et al., 1997; Lima et al., 2011), and it has since been widely disseminated and applied to breeding programs for this genus.

Another possible result of this experiment would be the transformation into a breeding-seed production area, called seed orchard by seedling. However, as the implementation of this experiment was carried out on private land, thinning of inferior trees was not feasible, as it would compromise the income of the producer, who commercializes leaf production throughout the years. Therefore, the maintenance of the experiment without thinning was adopted, which also contributes to a greater genetic conservation of the evaluated

Table 5. Selection gains and efficiency of the early selection for leaf mass production from open-pollinated progenies of yerba mate (Ilex paraguariensis), in the municipality of Ivaí, in the state of Paraná, Brazil.

\begin{tabular}{lcccc}
\hline Estimate & \multicolumn{4}{c}{ Pairs of age at harvest (years) } \\
\cline { 2 - 5 } & $2.5 / 18.7$ & $4.5 / 18.7$ & $6.5 / 18.7$ & $18.7 / 18.7$ \\
\hline Average base population & 2.7140 & 3.0827 & 4.1756 & 6.9330 \\
Selection gain & 0.2405 & 0.9432 & 2.1938 & 16.2432 \\
Selection gain (\%) & 8.8615 & 30.5965 & 52.5386 & 234.2882 \\
Gain per year (\%) & 3.5446 & 6.7992 & 8.0829 & 12.5288 \\
Selection efficiency (\%) & 28.2916 & 54.2685 & 64.5145 & 100.00 \\
\hline
\end{tabular}


germplasm. Furthermore, the major goal of this trial was to select the best parents and clone candidates.

Thus, a selection intensity of $21.3 \%$ was applied, which culminated in the selection of the 30 best parents, based on the predicted additive genetic value $(u+a)$, with a selection gain of $234.3 \%$ for the leaf mass production trait (Table 6). The predicted additive genetic values are important both for the selection of parents used in controlled crosses and the advancement of generations in recurrent selection. The execution of crosses in yerba mate, according to the already developed method of artificial pollination (Sousa et al., 2015), could generate bred seeds of materials with high potential for leaf mass production, since the breeding exceds in the accumulation of advantages with the advancement of generations (Resende \& Barbosa, 2005).

The selection of the best 30 clones, based on the predicted genotypic value $(\mathrm{u}+\mathrm{g})$, resulted in a gain of $372.6 \%$ for leaf mass production trait (Table 6). Cloning, unlike sexual propagation, is a strategy that leads to the maximization of gains, as it uses all available genetic variance (Resende \& Barbosa, 2005).

Cloning of yerba mate is feasible by its ability to resprout and by the rooting of cuttings and minicuttings

Table 6. Parents and superior clones selected from open-pollinated progenies of yerba mate (Ilex paraguariensis), in the municipality of Ivaí, in the state of Paraná, Brazil, at 18.7 years of age.

\begin{tabular}{|c|c|c|c|c|c|c|c|c|}
\hline \multirow[t]{2}{*}{ Order } & \multicolumn{4}{|c|}{ Selection of parents } & \multicolumn{4}{|c|}{ Selection of clones } \\
\hline & Replicate & Progeny & Tree & $\mathrm{u}+\mathrm{a}^{(1)}$ & Replicate & Progeny & Tree & $\mathrm{u}+\mathrm{g}^{(2)}$ \\
\hline 1 & 7 & 61 & 3 & 29.0150 & 8 & 126 & 5 & 43.2558 \\
\hline 2 & 8 & 126 & 5 & 28.1988 & 4 & 104 & 4 & 42.1892 \\
\hline 3 & 4 & 104 & 4 & 28.1680 & 7 & 61 & 3 & 41.2706 \\
\hline 4 & 7 & 3 & 2 & 26.7686 & 7 & 3 & 2 & 38.5440 \\
\hline 5 & 8 & 61 & 3 & 25.6569 & 4 & 25 & 5 & 36.9683 \\
\hline 6 & 4 & 25 & 5 & 25.5621 & 8 & 61 & 3 & 35.6737 \\
\hline 7 & 6 & 69 & 4 & 24.1204 & 6 & 69 & 4 & 35.2265 \\
\hline 8 & 5 & 4 & 3 & 23.8672 & 3 & 42 & 2 & 34.2259 \\
\hline 9 & 7 & 14 & 2 & 23.6182 & 5 & 4 & 3 & 33.8509 \\
\hline 10 & 4 & 15 & 2 & 23.3602 & 7 & 14 & 2 & 33.5410 \\
\hline 11 & 5 & 53 & 6 & 23.3349 & 4 & 15 & 2 & 32.7794 \\
\hline 12 & 6 & 21 & 2 & 22.8835 & 6 & 21 & 2 & 32.3791 \\
\hline 13 & 6 & 5 & 4 & 22.8765 & 9 & 126 & 2 & 31.6516 \\
\hline 14 & 5 & 10 & 3 & 22.8438 & 9 & 38 & 1 & 31.5754 \\
\hline 15 & 3 & 53 & 3 & 22.5815 & 5 & 10 & 3 & 31.4688 \\
\hline 16 & 1 & 153 & 1 & 22.4685 & 1 & 153 & 1 & 31.2896 \\
\hline 17 & 3 & 42 & 2 & 22.4198 & 5 & 53 & 6 & 31.1032 \\
\hline 18 & 8 & 81 & 5 & 21.9981 & 6 & 5 & 4 & 30.8957 \\
\hline 19 & 5 & 10 & 1 & 21.7513 & 8 & 81 & 5 & 30.5390 \\
\hline 20 & 2 & 65 & 3 & 21.6089 & 4 & 9 & 1 & 29.9626 \\
\hline 21 & 4 & 53 & 1 & 21.5944 & 3 & 53 & 3 & 29.8476 \\
\hline 22 & 4 & 9 & 1 & 21.5909 & 8 & 125 & 2 & 29.7575 \\
\hline 23 & 7 & 64 & 2 & 21.3724 & 5 & 10 & 1 & 29.6480 \\
\hline 24 & 9 & 84 & 5 & 21.2749 & 8 & 23 & 6 & 29.5378 \\
\hline 25 & 9 & 126 & 2 & 21.2363 & 5 & 38 & 1 & 29.5221 \\
\hline 26 & 9 & 38 & 1 & 21.2145 & 2 & 98 & 4 & 29.3782 \\
\hline 27 & 2 & 98 & 4 & 21.1965 & 2 & 65 & 3 & 29.3769 \\
\hline 28 & 8 & 61 & 2 & 21.1504 & 7 & 64 & 2 & 29.3671 \\
\hline 29 & 2 & 76 & 6 & 20.9375 & 4 & 20 & 5 & 29.2416 \\
\hline 30 & 6 & 93 & 3 & 20.6181 & 6 & 18 & 5 & 28.8682 \\
\hline \multicolumn{2}{|c|}{ Average breeding population } & & & 23.1762 & & & & 32.7645 \\
\hline \multicolumn{2}{|c|}{ Average base population } & & & 6.9329 & & & & 6.9329 \\
\hline \multicolumn{2}{|c|}{ Selection gain } & & & 16.2432 & & & & 25.8316 \\
\hline \multicolumn{2}{|c|}{ Selection gain $(\%)$} & & & 234.2915 & & & & 372.5944 \\
\hline
\end{tabular}

${ }^{(1)} \mathrm{u}+\mathrm{a}$, additive genotypic value. ${ }^{(2)} \mathrm{u}+\mathrm{g}$, genotypic value. 
(Santin et al., 2008; Bitencourt et al., 2009; Stuepp et al., 2015; Wendling \& Santin, 2015), which makes it possible to multiply the selected individuals and to confirm the genetic superiority in clonal trials in several places with contrasting environmental conditions (Resende \& Barbosa, 2005). There was $80 \%$ agreement between the genotypes selected for sexual and asexual propagation, which guarantees collections of seed of individuals with high genetic potential from the clonal trials to be conducted.

In subsequent stages, evaluations will be performed for the traits related to the relevant chemical compounds, present in the leaves of the yerba mate clones, as they can directly affect the quality of commercial products and their biological effects. Subsequently, there will be recommendations of superior clones, and the consequent registration and protection of cultivars for interested producers.

The use of yerba mate clones for commercial crops has been increasing due to the enormous potential to overcome the current levels of leaf mass productivity. Cloning also contributes to a greater uniformity, which facilitates the silviculture treatments applied to the crop, and increases the tolerance to biotic and abiotic factors. In addition, it results in greater homogeneity and better quality of the harvested leaf mass. These aspects contribute to the income maximization to producers and the industries that depend on yerba mate (Wendling et al., 2015).

\section{Conclusions}

1. Early selection for leaf mass production is feasible for yerba mate (Ilex paraguariensis) progenies at 6.5 years of age.

2. Selection of the best trees, either for use as parents or candidates for cloning, provides significant gains to breed yerba mate.

\section{Acknowledgments}

To Chimarrão Bitumirim Indústria e Comércio de Erva-Mate Ltda., for all the support in conducting this experiment.

\section{References}

ANESINI, C.; TURNER, S.; COGOI, L.; FILIP, R. Study of the participation of caffeine and polyphenols on the overall antioxidant activity of mate (Ilex paraguariensis). LWT - Food Science and Technology, v.45, p.299-304, 2012. DOI: 10.1016/j. lwt.2011.06.015.

BARBOSA, J.Z.; ZAMBON, L.M.; MOTTA, A.C.V.; WENDLING, I. Composition, hot-water solubility of elements and nutritional value of fruits and leaves of yerba mate. Ciência e Agrotecnologia, v.39, p.593-603, 2015. DOI: 10.1590/S141370542015000600006.

BELTRAME, R.; BISOGNIN, D.A.; MATTOS, B.D.; CARGNELUTTI FILHO, A.; HASELEIN, C.R.; GATTO, D.A.; SANTOS, G.A. dos. Desempenho silvicultural e seleção precoce de clones de híbridos de eucalipto. Pesquisa Agropecuária Brasileira, v.47, p.791-796, 2012. DOI: 10.1590/S0100204X2012000600009.

BITENCOURT, J.; ZUFFELLATO-RIBAS, K.C.; WENDLING, I.; KOEHLER, H. Enraizamento de estacas de erva-mate (Ilex paraguariensis A. St.-Hill.) provenientes de brotações rejuvenescidas. Revista Brasileira de Plantas Medicinais, v.11, p.277-281, 2009. DOI: 10.1590/S1516-05722009000300008.

BLUM-SILVA, C.H.; CHAVES, V.C.; SCHENKEL, E.P.; COELHO, G.C.; REGINATTO, F.H. The influence of leaf age on methylxanthines, total phenolic content, and free radical scavenging capacity of Ilex paraguariensis aqueous extracts. Revista Brasileira de Farmacognosia, v.25, p.1-6, 2015. DOI: 10.1016/j.bjp.2015.01.002.

CARDOZO JUNIOR, E.L.; MORAND, C. Interest of mate (Ilex paraguariensis A. St.-Hil.) as a new natural functional food to preserve human cardiovascular health: a review. Journal of Functional Foods, v.21, p.440-454, 2016. DOI: 10.1016/j. jff.2015.12.010.

COSTA, R.B. da; RESENDE, M.D.V. de; CONTINI, A.Z.; REGO, F.L.H.; ROA, R.A.R.; MARTINS, W.J. Avaliação genética de indivíduos de erva-mate (Ilex paraguariensis St. Hil.), na região de Caarapó, MS, pelo procedimento REML/BLUP. Ciência Florestal, v.15, p.371-376, 2005. DOI: 10.5902/198050981874.

GONZÁLEZ ARBELÁEZ, L.F.; FANTINELLI, J.C.; PARDO, A.C.; CALDIZ, C.I.; RÍOS, J.L.; SCHINELLA, G.R.; MOSCA, S.M. Effect of an Ilex paraguariensis (yerba mate) extract on infarct size in isolated rat hearts: the mechanisms involved. Food \& Function, v.7, p.816-824, 2016. DOI: 10.1039/c5fo01255d.

GONZÁLEZ DE MEJÍA, E.G.; SONG, Y.S.; HECK, C.I.; RAMÍREZ-MARES, M.V. Yerba mate tea (Ilex paraguariensis): phenolics, antioxidant capacity and in vitro inhibition of colon cancer cell proliferation. Journal of Functional Foods, v.2, p.2334, 2010. DOI: 10.1016/j.jff.2009.12.003.

IBGE. Sistema IBGE de recuperação automática - SIDRA. Rio de Janeiro, 2015. Available at: <https://sidra.ibge.gov.br/ home/ipca15/brasil >. Accessed on: Jan. 312017.

LAMBETH, C.C. Juvenile-mature correlations in Pinaceae and implications for early selection. Forest Science, v.26, p.571-580, 1980.

LIMA, J.L.; SOUZA, J.C. de; RAMALHO, M.A.P.; ANDRADE, H.B.; SOUSA, L.C. de. Early selection of parents and trees in Eucalyptus full-sib progeny tests. Crop Breeding and Applied Biotechnology, v.11, p.10-16, 2011. DOI: 10.1590/S198470332011000100002.

MARQUES JÚNIOR, O.G.; ANDRADE, H.B.; RAMALHO, M.A.P. Assessment of the early selection efficiency in Eucalyptus 
cloeziana F. Muell. in the northwest of Minas Gerais state (Brazil). Silvae Genetica, v.45, p.359-361, 1996.

MASSARO, R.A.M.; BONINE, C.A.V.; SCARPINATI, E.A.; PAULA, R.C. de. Viabilidade de aplicação da seleção precoce em testes clonais de Eucalyptus spp. Ciência Florestal, v.20, p.597609, 2010.

MORAIS, E.C. de; STEFANUTO, A.; KLEIN, G.A.; BOAVENTURA, B.C.; ANDRADE, F. de; WAZLAWIK, E.; DI PIETRO, P.F.; MARASCHIN, M.; SILVA, E.L. da. Consumption of yerba mate (Ilex paraguariensis) improves serum lipid parameters in healthy dyslipidemic subjects and provides an additional LDL-cholesterol reduction in individuals on statin therapy. Journal of Agricultural and Food Chemistry, v.57, p.8316-8324, 2009. DOI: 10.1021/jf901660g.

PEREIRA, A.B.; MARQUES JÚNIOR, O.G.; RAMALHO, M.A.P.; ALTHOFF, P. Eficiência da seleção precoce em famílias de meios irmãos de Eucalyptus camaldulensis Dehnh., avaliadas na região noroeste do Estado de Minas Gerais. Revista Cerne, v.3, p.67-81, 1997.

RESENDE, M.D.V. de; BARBOSA, M.H.P. Melhoramento genético de plantas de propagação assexuada. Colombo: Embrapa Florestas, 2005. 130p.

RESENDE, M.D.V. de; DUARTE, J. B. Precisão e controle de qualidade em experimentos de avaliação de cultivares. Pesquisa Agropecuária Tropical, v.37, p.182-194, 2007.

RESENDE, M.D.V. de. Matemática e estatística na análise de experimentos e no melhoramento genético. Colombo: Embrapa Florestas, 2007b. 561p.

RESENDE, M.D.V. de. SELEGEN-REML/BLUP: sistema estatístico e seleção genética computadorizada via modelos lineares mistos. Colombo: Embrapa Florestas, 2007a. 359p.

SANTIN, D.; BENEDETTI, E.L.; BARROS, N.F. de; ALMEIDA, I.C. de; LEAL, G.P.; FONTES, L.; NEVES, J.C.L.; WENDLING, I.; REISSMANN, C.B. Effect of potassium fertilization on yield and nutrition of yerba mate (Ilex paraguariensis). Revista Brasileira de Ciência do Solo, v.38, p.1469-1477, 2014. DOI: 10.1590/S0100-06832014000500012.

SANTIN, D.; WENDLING, I.; BENEDETTI, E.L.; BRONDANI, G.; REISSMANN, C.B.; MORANDI, D.; ROVEDA, L.F. Poda e anelamento em erva-mate (Ilex paraguariensis) visando à obtenção de brotações basais. Pesquisa Florestal Brasileira, v.56, p.97-104, 2008.

SANTIN, D; WENDLING, I.; BENEDETTI, E.L.; MORANDI, D.; DOMINGOS, D.M. Sobrevivência, crescimento e produtividade de plantas de erva-mate produzidas por miniestacas juvenis e por sementes. Ciência Florestal, v.25, p.571-579, 2015.

SCHERER, R.A. Mass and nursery selection of yerba mate (Ilex paraguariensis St. Hil) for quality improvement in Argentina. 2001. 203p. Dissertation (Master) - Curvillier Verlag, Göttingen.

SIMEÃO, R.M.; STURION, J.A.; RESENDE, M.D.V. de; FERNANDES, J.S.C.; NEIVERTH, D.D.; ULBRICH, A.L. Avaliação genética em erva-mate pelo procedimento BLUP individual multivariado sob interação genótipo $\mathrm{x}$ ambiente. Pesquisa Agropecuária Brasileira, v.37, p.1589-1596, 2002. DOI: 10.1590/S0100-204X2002001100010.

SOUSA, V.A. de; AGUIAR, A.V. de; SPOLADORE, J. Metodologia para a polinização controlada em Ilex paraguariensis A. St. Hil. - Aquifoliaceae. Revista Árvore, v.39, p.315-323, 2015. DOI: $10.1590 / 0100-67622015000200011$.

STUEPP, C.A.; BITENCOURT, J. de; WENDLING, I.; KOEHLER, H.S.; ZUFFELLATO-RIBAS, K.C. Propagação de erva-mate utilizando brotações de anelamento e decepa em matrizes de duas idades. Cerne, v.21, p.519-526, 2015. DOI: 10.1590/01047760201521041864.

STURION, J.A.; RESENDE, M.D.V. de. Melhoramento genético da erva-mate. Colombo: Embrapa Florestas, 2010. 274p.

VENCOVSKY, R.; BARRIGA, P. Genética biométrica no fitomelhoramento. Ribeirão Preto: Sociedade Brasileira de Genética, 1992. 496p.

WENDLING, I.; SANTIN, D. (Ed.). Propagação e nutrição de erva-mate. Brasília: Embrapa, 2015. 195p.

WENDLING, I.; STURION, J.A.; REIS, C.A.F; STUEPP, C.A.; PEÑA, M.L.P. Indirect and expedite assessment of Ilex paraguariensis commercial yield. Cerne, v.22, p.241-248, 2016. DOI: $10.1590 / 01047760201622032189$. 